\title{
Identifikasi Bakteri Salmonella sp. Pada Telur yang dijual di Pasar Kota Kendari Provinsi Sulawesi Tenggara
}

\author{
SATYA DARMAYANI ${ }^{1}$, ANITA ROSANTY $^{1}$, VINA VANDUWINATA $^{1}$ \\ ${ }^{1}$ Jurusan Analis Kesehatan, Politeknik Kesehatan Kementerian Kesehatan Kendari \\ J1. Jend. A.H.Nasution No. 614 Anduonohu, Kendari, Sulawesi Tenggara 93127 \\ email: satya.darmayani@gmail.com
}

\begin{abstract}
This study aimed to identify the presence of Salmonella sp. in eggs sold in the market of Kendari. The World Health Organization (WHO) declared Salmonella sp. is a genus of bacteria that is a major cause of food borne illness in the entire world. Two factors that cause Salmonella sp. contained in eggs are internal and external factors that cause diarrhea or gastroenteritis. The sampling technique was done by purposive sampling, the population is the seller of eggs located in the market of Kendari city that is as much as 172 egg sellers with the sample size are 34 egg samples of chicken. In the process of planting samples on Brain Heart Infusion Broth (BHIB) media, all positive samples were cloudy, indicating bacterial growth in the sample. Furthermore, bacteria were inoculated in Salmonella Shigella Agar (SSA) medium which obtained negative results from 34 samples, no Salmonella sp. colony growth on SSA medium. So it can be concluded, the sample of chicken eggs in this study declared not contaminated by Salmonella sp.
\end{abstract}

Keywords: eggs, Salmonella Shigella Agar (SSA), Salmonella sp.

\section{INTISARI}

Penelitian ini bertujuan untuk mengidentifikasi keberadaan bakteri Salmonella sp. pada telur yang dijual di Pasar kota Kendari. Badan Kesehatan Dunia (WHO) menyatakan Salmonella sp. adalah genus bakteri yang merupakan penyebab utama penyakit bawaan makanan di seluruh dunia. Penyebab adanya Salmonella sp. pada telur di sebab oleh dua faktor yaitu faktor internal dan faktor eksternal yang dapat mengakibatkan diare atau gastroenteritis. Teknik pengambilan sampel dilakukan secara purposive sampling, populasi dalam penelitian ini adalah penjual telur yang berada di pasar kota Kendari yakni sebanyak 172 penjual telur dengan besar sampel adalah 34 sampel telur ayam ras. Pada proses penanaman sampel pada media Brain Heart Infusion Broth (BHIB) seluruh sampel positif keruh yang menandakan adanya pertumbuhan bakteri pada sampel. Selanjutnya bakteri diinokulasi pada media Salmonella Shigella Agar (SSA) dan diperoleh hasil negatif dari 34 sampel yaitu tidak ada pertumbuhan koloni Salmonella sp. pada media SSA. Sehingga dapat disimpulkan sampel telur ayam ras pada penelitian ini dinyatakan tidak terkontaminasi oleh bakteri Salmonella sp.

Kata kunci: bakteri Salmonella sp., Salmonella Shigella Agar (SSA), telur

\section{PENDAHULUAN}

Badan Kesehatan Dunia (WHO, 2014) menyatakan Salmonella adalah genus bakteri yang merupakan penyebab utama penyakit bawaan makanan di seluruh dunia. Sampai saat ini masih terbatasnya studi di laboratorium, dan kurangnya penyelidikan Salmonellosis di negara berkembang membuat resiko penyakit akibat infeksi Salmonella ini semakin besar.
Salmonella sp. adalah salah satu spesies bakteri yang termasuk dalam anggota family Enterobacteriaceae. Habitat utamanya berada dalam saluran pencernaan hewan dan manusia (Portillo, 2000). Bakteri Salmonella sp. biasanya ditemukan pada bahan pangan yang mengandung protein cukup tinggi sebagai media yang baik bagi pertumbuhan mikroorganisme. Salah satu jenis bahan pangan yang mengandung protein tinggi 
adalah telur. Dalam keadaan tertentu atau dalam jumlah yang melebihi batas, mikroorganisme yang berada dalam telur tersebut dapat menyebabkan keracunan bagi yang mengkonsumsinya. Kemungkinan keracunan akan lebih tinggi pada konsumen yang mengkonsumsi telur mentah, misalnya sebagai campuran jamu, karena mikroorganisme yang berada dalam telur tidak mengalami proses pematangan (Setiawan, 2008).

Hasil Monitoring dan surveilans yang dilakukan oleh Yogaswara dan Setia (2005) mendapatkan hasil bahwa pada tahun 20032004 terdapat 9 kasus cemaran Salmonella pada telur di Indonesia. Keadaan ini sesuai dengan temuan Nugroho (2006) yang melaporkan bahwa cemaran Salmonella di Sleman Yogyakarta mencapai 1,4\% pada telur ayam. Hasil penelitian juga dilaporkan oleh Chusniati dkk (2009) bahwa 5,56\% dari 36 sampel telur ayam buras yang dijual sebagai campuran jamu di Kecamatan Sidoarjo positif tercemar Salmonella sp.

Telur yang berasal dari peternakan pada umumnya banyak diperdagangkan di pasar tradisional. Distribusi telur ayam ras dan telur puyuh dari peternak ke pengecer memerlukan waktu 1-8 hari. Setelah itu telur-telur yang dijual di pasar tradisional hanya ditempatkan di rak-rak telur seperti karton yang bercekung-cekung pada ruang terbuka (tidak disimpan dalam ruangan AC). Telur-telur tersebut kemudian di simpan lagi selama beberapa hari apabila belum terjual, sedangkan kondisi ketahanan telur yang disimpan tanpa pengawetan hanya mampu bertahan sekitar delapan hari, ditinjau dari batas telur ekonomis untuk dikonsumsi (Saraswati, 2012).

Kasus penyakit diare akibat Salmonella sp. di Sulawesi Tenggara tahun 2012 masih menjadi masalah kesehatan masyarakat, walaupun secara umum angka kesakitan dan kematian akibat diare yang dilaporkan oleh sarana pelayanan kesehatan mengalami penurunan, namun demikian diare sering menimbulkan Kejadian Luar Biasa (KLB) dan berujung pada kematian. Jumlah perkiraan kasus diare akibat Salmonella sp. di Provinsi
Sulawesi Tenggara tahun 2012 berjumlah 96.644 kasus dari total penduduk 2.310.083 jiwa. Total diare yang ditangani Tahun 2012 sebesar $60.48 \%$.

Berdasarkan hasil observasi di Pasar Kota Kendari yang terdiri dari Pasar Sentral Kota, Pasar Mandonga, Pasar Lawata, Pasar Anduonohu, Pasar Panjang dan Pasar Baruga terdapat 105 penjual telur. Rata-rata masih menjual telur yang disimpan lebih dari 2 minggu untuk dijual. Lama penyimpanan telur di pasar yaitu 1-2 minggu. Apabila penyimpanannya lebih dari 2 minggu dan penanganannya tidak dilakukan dengan baik maka kemungkinan besar telur dapat terkontaminasi oleh Salmonella sp. dan dapat menyebabkan diare bagi yang mengkonsumsinya.

\section{METODE}

Populasi dan Sampel. Populasi dalam penelitian ini adalah penjual telur yang berada di Pasar Kota Kendari. Berdasarkan hasil observasi yang dilakukan peneliti pada tiaptiap Pasar seperti Pasar Mandonga dan Pasar Panjang diperoleh penjual telur sebanyak 172 penjual telur. Teknik pengambilan sampel dilakukan secara purposive sampling dengan pertimbangan tertentu (Sugiyono, 2011). Jika populasi $>100$ maka sampel diambil 15-30\% dan jika besarnya populasi $<100$ maka sampel diambil 25-50\% (Notoatmodjo, 2002). Besar sampel dalam penelitian ini adalah 34 sampel ditentukan dengan cara sebagai berikut:

$$
172 \times \frac{20}{100}=34
$$

Sterilisasi Alat Penelitian. Alat-alat yang terbuat dari kaca atau logam dengan skala dan keakuratan rendah disterilkan dalam oven dengan suhu $180^{\circ} \mathrm{C}$ selama 24 jam. Sedangkan alat-alat yang terbuat dari kaca yang memiliki tingkat skala dan keakuratan tinggi atau plastik disterilkan dalam autoclave dengan suhu $121^{\circ} \mathrm{C}$ selama 15 menit.

Pembuatan Media Brain Heart Infusion Broth (BHIB) (Andrianto, 2012). Media BHIB ditimbang sebanyak 11,322 gram. Kemudian dimasukkan ke dalam 
erlenmeyer $306 \mathrm{~mL}$ dan dilarutkan dengan akuades sebanyak $60 \mathrm{~mL}$, $\mathrm{pH}$ diukur dengan indikator $\mathrm{pH} 7,4 \pm 0,2$. Kemudian dipanaskan sampai larut dengan baik dan disterilisasi dengan autoclave pada suhu $121^{\circ} \mathrm{C}$ selama 15 menit.

Pembuatan SSA. Media SSA ditimbang 10,2 gram dan dimasukkan ke dalam erlenmeyer $170 \mathrm{~mL}$ kemudian dilarutkan dengan akuades sebanyak $120 \mathrm{~mL}, \mathrm{pH}$ diukur

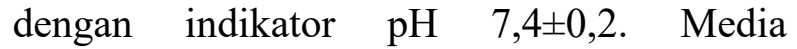
dipanaskan sampai larut dengan baik, dan disterilisasi dengan autoclave pada suhu $121^{\circ} \mathrm{C}$ selama 15 menit.

\section{Penanaman Bakteri Pada Media} BHIB. Sampel telur ayam kampung dihomogenkan dan diisolasi pada media BHIB dengan perbandingan 9:1. $9 \mathrm{ml}$ untuk media BHIB dan $1 \mathrm{ml}$ untuk sampel telur.
Media BHIB diinkubasi selama 1x24 jam pada suhu $37^{\circ} \mathrm{C}$ di inkubator.

Observasi hasil dilakukan dengan melihat kekeruhan pada media BHIB dan media selektif yaitu media SSA.

Penanaman Bakteri Pada Media SSA. Bakteri yang terdapat di media BHIB diambil dengan menggunakan ose yang sudah difiksasi, kemudian diinokulasi pada media SSA dengan cara digoreskan. Media SSA tersebut diinkubasi selama $1 \times 24$ jam pada suhu $37^{\circ} \mathrm{C}$ di inkubator.

Observasi hasil dilakukan dengan melihat pertumbuhan koloni bakteri Salmonella sp. yang ditandai dengan adanya pertumbuhan koloni berwarna merah dengan titik hitam di tengah. Jika terdapat pertumbuhan, maka dilanjutkan dengan pewarnaan gram.

HASIL

Tabel 1. Distribusi frekuensi Pertumbuhan Bakteri di Media Brain Heart Infusion Broth (BHIB)

\begin{tabular}{|c|c|c|c|c|}
\hline $\begin{array}{l}\text { Pertumbuhan Bakteri } \\
\text { di Media BHIB }\end{array}$ & $\begin{array}{c}+/- \\
\text { Bakteri }\end{array}$ & $\begin{array}{c}\text { Kebutuhan } \\
\text { Oksigen }\end{array}$ & $\mathbf{N}$ & $\%$ \\
\hline Keruh & + & Aerob fakultatif & 34 & 100 \\
\hline Jernih & - & - & 0 & 0 \\
\hline \multicolumn{3}{|c|}{ Jumlah } & 34 & 100 \\
\hline
\end{tabular}

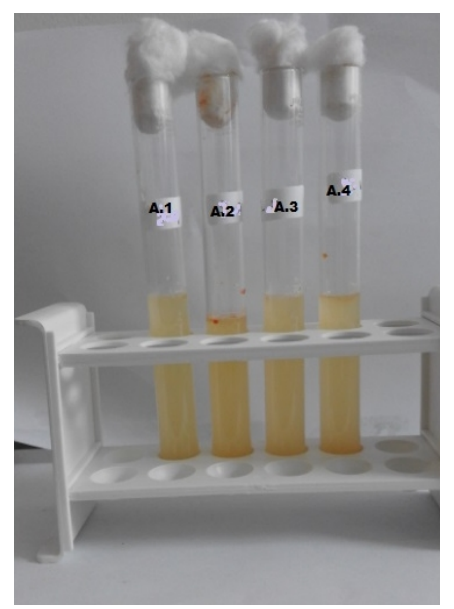

Gambar 1. Interprestasi hasil pertumbuhan bakteri pada media BHIB positif keruh

Tabel 2. Distribusi frekuensi pertumbuhan bakteri Salmonella sp. di media Salmonella Shigella Agar (SSA)

\begin{tabular}{cccc}
\hline Koloni Bakteri & $\begin{array}{c}+/- \\
\text { Bakteri }\end{array}$ & $\mathbf{n}$ & $\mathbf{\%}$ \\
\hline Ada pertumbuhan & - & 0 & 0 \\
\hline Tidak ada pertumbuhan & + & 100 & 100 \\
\hline Jumlah & & $\mathbf{3 4}$ & $\mathbf{1 0 0}$ \\
\hline
\end{tabular}



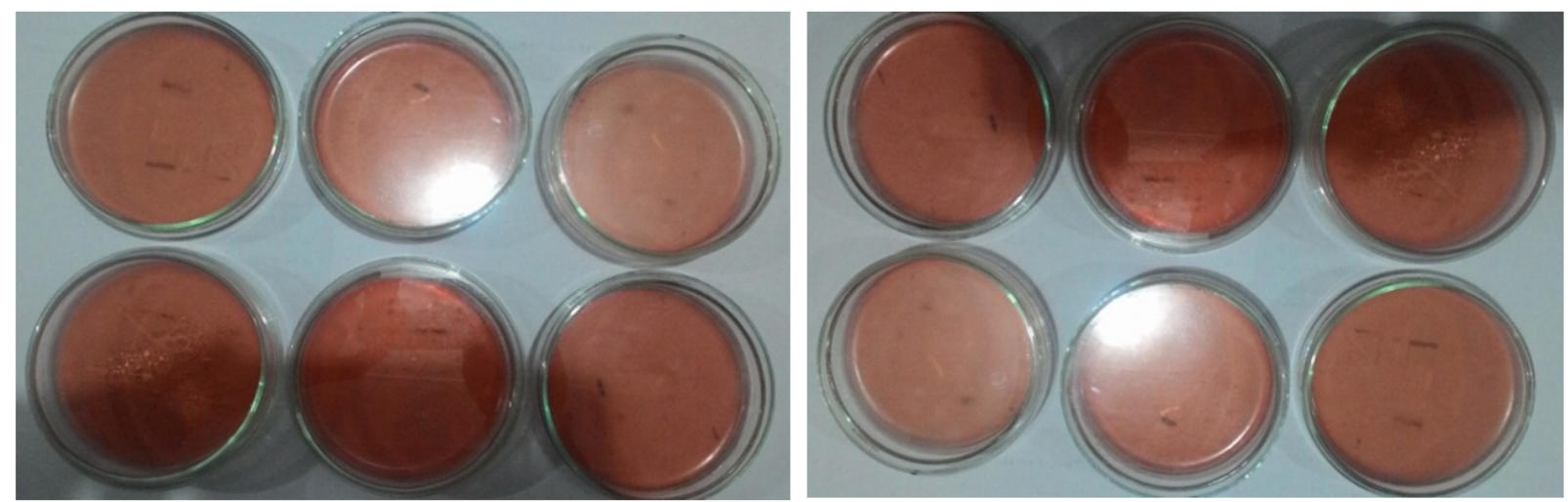

Gambar 2. Interpretasi hasil pertumbuhan bakteri Salmonella sp. pada media SSA, tidak ada pertumbuhan koloni berwarna merah dengan titik hitam di tengah

\section{PEMBAHASAN}

Sampel telur dalam penelitian ini diambil dari penjual telur di Pasar Kota Kendari. Teknik pengambilan sampel dilakukan secara Purposive Sampling. Dalam penelitian ini yang menjadi kriteria pemilihan sampel adalah telur yang tidak berbau dan kulit telur dalam keadaan bersih. Berdasarkan kriteria tersebut maka sampel yang diambil sebanyak 34 sampel yang diperoleh dari Pasar Mandonga dan Pasar Panjang masing-masing sebanyak 17 sampel telur.

Sampel yang telah diambil kemudian dibawa ke laboratorium, selanjutnya dilakukan penanaman sampel telur ayam ras pada media Brain Heart Infusion Broth (BHIB). BHIB adalah medium cair untuk berbagai mikroorganisme aerob dan anaerob. Inokulasi pada media BHIB dilakukan dengan mengamati kekeruhan yang menandakan adanya pertumbuhan bakteri pada sampel. Bakteri-bakteri yang terdapat pada media BHIB yaitu Enterobacter, Escherichia coli, Klebsiela, Proteus, Salmonella, Seratia, Yersinia, Vibrio dan Shigella (Andrianto, 2012).

Dari hasil inokulasi pada media Brain Heart Infusion Broth (BHIB), semua sampel positif keruh. Selanjutnya diinokulasi pada media Salmonella Shigella Agar (SSA). Media Salmonella Shigella Agar (SSA) merupakan media spesifik yang digunakan pada identifikasi bakteri Salmonella dan Shigella, sehingga bakteri lain tidak dapat tumbuh pada media tersebut. Untuk mengetahui adanya pertumbuhan koloni Salmonella sp. pada media SSA ditandai dengan adanya pertumbuhan koloni berwarna merah dengan titik hitam di tengah.

Berdasarkan hasil pengamatan dari 34 sampel telur ayam ras yang dijual di pasar Kota Kendari diperoleh hasil negatif terhadap Salmonella sp., yaitu tidak ada pertumbuhan koloni Salmonella pada media SSA. Hasil ini telah sesuai dengan anjuran pemerintah yang dituangkan dalam SNI No. 01-6366-2000 yang menyebutkan bahwa batas maksimum cemaran mikroba untuk telur segar dengan komponen residu Salmonella sp. adalah negatif dalam satuan kualitatif (Badan Standarisasi Nasional, 2000). Jika mengacu pada standar aturan tersebut maka kualitas telur ayam yang digunakan sudah tergolong baik.

Hal ini sejalan dengan penelitian yang dilakukan Saraswati (2012) dengan menggunakan medium selektif SSA dari 4 telur ayam kampung dan 4 telur puyuh yang menunjukkan hasil negatif. Hanya sampel telur bebek yang menunjukkan hasil positif. Dari 4 sampel yang diuji, sebanyak tiga sampel telur bebek diduga menunjukkan adanya bakteri Salmonella sp. Dalam penelitian lain Chusniati dkk (2009) mengungkapkan bahwa 36 sampel telur ayam buras yang dijual sebagai campuran jamu di Kecamatan Sidoarjo terdapat 5,56\% sampel positif terhadap Salmonella sp.

Penanganan yang baik dan benar terhadap telur bermanfaat untuk mencegah 
terjadinya kontaminasi Salmonella sp. Penyimpanan telur dalam suhu rendah sangat penting untuk mencegah pertumbuhan kontaminan Salmonella sp. dalam telur (Novitasari, 2008). Sistem penyimpanan telur yang dilakukan oleh pedagang umumnya diletakkan pada tempat terbuka dan pada suhu ruangan karena lebih praktis, hal ini dapat memicu terjadinya kontaminasi Salmonella sp. pada telur tersebut. Badan Standarisasi Nasional (2008) mengatur tentang standar telur ayam konsumsi melalui SNI No. 013926-2008 bahwa persyaratan utama telur aman dikonsumsi adalah harus dalam keadaan bersih, jika telur dalam keadaan kotor, dapat dibersihkan dengan berbagai cara, antara lain dengan menggunakan lap yang bersih dan kering serta pencucian menggunakan air hangat dengan suhu $35^{\circ} \mathrm{C}$, atau menggunakan senyawa Clorine Compound dan setelah pencucian telur harus segera dikeringkan. Adanya Salmonella sp. dalam telur merupakan salah satu indikasi bahwa perlakuan telur oleh produsen tidak sesuai dengan standar yang ada. Hal ini berakibat pada penurunan kualitas telur, karena lapisan kutikula pada kulit telur sebagai pertahanan terhadap bakteri hilang, sehingga bakteri dengan mudah akan langsung masuk ke dalam telur.

\section{KESIMPULAN}

Berdasarkan hasil penelitian idenfikasi bakteri Salmonella sp. pada telur yang dijual di pasar Kota Kendari Provinsi Sulawesi Tanggara, tidak terdapat bakteri salmonella sp. pada sampel telur ayam ras. Dari 34 sampel telur ayam ras yang dijual di pasar Kota Kendari diperoleh sampel negatif terhadap Salmonella sp., tidak ada pertumbuhan koloni pada media SSA. Sehingga dapat disimpulkan bahwa sampel telur ayam ras pada penelitian ini dinyatakan tidak terkontaminasi oleh bakteri Salmonella sp. Namun tidak menutup kemungkinan bakteri lain dapat mengkontaminasi telur ayam ras karena pada media BHIB terjadi kekeruhan yang artinya ada pertumbuhan bakteri di dalamnya.

\section{DAFTAR PUSTAKA}

Badan Standarisasi Nasional. 2000. Batas Maksimum Cemaran Mikroba pada Telur. SNI 01-6366-2000. Jakarta.

Badan Standardisasi Nasional . 2008. Telur Ayam Konsumsi. SNI 01-3926-2008. Jakarta.

Chusniati S, Budiono RN, Kurnijasanti R. 2009. Deteksi Salmonella sp. Pada Telur Ayam Buras yang dijual Sebagai Campuran Jamu di Kecamatan Sidoarjo. Journal of Poultry Diseases. vol 2(1): 2023.

Notoatmodjo S. 2002. Metodologi Penelitian Kesehatan. Jakarta: Rineka Cipta. hal 50.

Novitasari L. 2008. Deteksi Salmonella sp. pada Daging Ayam Broiler yang dijual di Pasar Traditional Menur Surabaya. [Skripsi]. Surabaya: Fakultas Kedokteran Hewan, Universitas Airlangga.

Nugroho WS. 2006. Analisis Tingkat Cemaran Salmonella dan Faktor-Faktor Pencemarannya pada Telur Ayam Ras di Kabupaten Sleman, Yogyakarta. Jurnal Veteriner Fakultas Kedokteran Hewan Universitas Udayana, Bali. vol 7(2):4753.

Portillo FG. 2000. Molecular and Cellular Biology of Salmonella Pathogenesis in Microbial Foodborne Disease: Mechanisms of Pathogenesis and Toxin Synthesis. $1^{\text {st }}$ ed. Technomic Publishing Company Inc. Pennysylvania, USA. pp 3-7.

Saraswati D. 2012. Uji Bakteri Salmonella sp. Pada Telur Bebek, Tekur Puyuh dan Telur Ayam Kampung yang di Perdagangkan di Pasar Liluwo Kota Gorontalo. [Tesis]. Gorontalo: Universitas Negeri Gorontalo.

Setiawan G. 2008. Deteksi Bakteri Salmonella sp. Pada Telur Ayam Buras di Beberapa Pasar Traditional Wilayah Surabaya Timur. [Skripsi]. Surabaya: Fakultas Kedokteran Hewan, Universitas Airlangga.

Sugiyono. 2011. Metode Penelitian Pendidikan (Pendekatan Kuantitatif, Kualitatif, dan R\&D). Bandung: Alfabeta. hal 35. 
World Health Organization(WHO). 2014. Drug Resistant Salmonella. http://www.who.int/. Diakses Januari 2017.

Yogaswara Y, Setia L. 2005. Kajian Hasil Monitoring dan Surveilans Cemaran
Mikroba dan Residu Obat Hewan pada Produk Pangan Asal Hewan di Indonesia. Prosiding Lokakarya Nasional Keamanan Pangan Produk Peternakan. 14 September 2005. Bogor: Pusat penelitian dan Pengembangan Peternakan. hal 144-148. 